\title{
Indicadores do Mercado de Trabalho do Sistema Agroindustrial da Cana-de-Açúcar do Brasil no Período 1992-2005
}

\author{
- Márcia Azanha Ferraz dias de Moraes*
}

\begin{abstract}
RESUMO
Este trabalho analisa os ambientes institucional e organizacional do mercado de trabalho do setor sucroalcooleiro do Brasil, e apresenta seus indicadores sociais para o período 1992-2005. As fontes de dados são as PNADs (Pesquisa Nacional por Amostra de Domicílios) do IBGE (Instituto Brasileiro de Geografia e Estatística) e os Registros Administrativos da RAIS (Relação Anual de Informações Sociais) do Ministério do Trabalho e Emprego. No setor de cana-de-açúcar, verificou-se redução de $23 \%$ do número de empregados entre 1992 e 2005, a despeito do crescimento da produção de 54,6\%; do total de 519.917 empregados, 27, $1 \%$ são informais; o nível de educação dos empregados do setor de cana-de-açúcar tem evoluído positivamente, mas ainda é baixo: em 2005, 70\% tinham até quatro anos de estudo e existia uma parte significativa de analfabetos (29\%) (PNAD). Segundo os registros da RAIS, os maiores salários médios mensais foram pagos pela indústria do álcool $(R \$ 706,29)$, seguidos pela indústria do açúcar ( $R \$$ 698,99), e pelo setor agrícola $(R \$ 647,22)$.
\end{abstract}

\section{Palavras-CHave}

mercado de trabalho, sistema agroindustrial da cana-de-açúcar, ambiente institucional, ambiente organizacional

\section{Abstract}

This study analyzes the institutional and organizational environment of the labor market of the sugar alcohol sector, and presents its social indicators for the period 1992-2005. Two databases were used: RAIS (Administrative Registers of the Ministry of Work and Labor) and PNADs (National Research for Sample of Domiciles). It was observed in the sugar cane production a reduction of $23 \%$ of the number of employees between 1992 and 2005, in despite of the growth of $54.6 \%$ in the sugar cane production; $27.1 \%$ of the total 519.917 employees of the sugar cane sector are informal; the education level of the sugar cane employees is still low: in 2005, $70 \%$ had up to 4 years of schooling and $29 \%$ were illiterate (PNAD). According to RAIS database, average monthly income ${ }^{1}$ for the year of 2005 was US\$330.35 in the alcohol industry; US\$326.94 for the sugar mill industry and US\$302.72 for the agricultural employees.

\section{KEY WORDS}

labor market, sugar cane agro-system, institutional environment, organizational environment

\section{JEL Classification}

$J 21, J 43$

\footnotetext{
* Professora Doutora no Departamento de Economia, Administração e Sociologia da Escola Superior de Agricultura "Luiz de Queiroz" - USP. Tel. para contato: (19) 3417-87I6 - E-mail: mafdmora@esalq.usp.br

(Recebido em novembro de 2005. Aceito para publicação em março de 2007).

1 Considering the exchange rate of US $\$ 1=2.138$.
} 


\section{INTRODUÇÃO}

As recentes indagações do Brasil junto à Organização Mundial do Comércio, referentes às políticas comerciais protecionistas no mercado mundial de açúcar (cotas tarifárias, subsídios às exportações) adotadas pela União Européia e Estados Unidos, fazem emergir a questão da competitividade da agroindústria canavieira nacional: alguns países concorrentes do Brasil argumentam que a competitividade brasileira advém do não cumprimento das normas ambientais e trabalhistas. Este artigo tem como objetivo, portanto, fazer uma análise da evolução recente dos indicadores do mercado de trabalho deste setor no Brasil, evidenciando os dados dos principais Estados produtores: São Paulo, Alagoas, Pernambuco, Minas Gerais e Paraná.

O setor de açúcar e álcool nacional tem passado por profundas alterações nos anos recentes, ${ }^{2}$ com impactos importantes sobre a organização setorial, estratégias empresariais e sobre o mercado de trabalho.

Desde 1999, o Estado afastou-se consideravelmente deste setor; atualmente os preços dos produtos são formados em livre mercado, o que impôs um novo padrão de competitividade às usinas de açúcar e/ou álcool, induzindo-as a buscar estratégias competitivas visando redução de custos e aumento de competitividade para sobrevivência neste novo ambiente competitivo.

Conforme Vian (2003), as usinas adotaram diferentes estratégias: diversificaram os tipos de açúcar produzido, passando a produzir açúcar líquido, açúcar orgânico, mistura de açúcar com adoçantes artificiais; difundiram a comercialização e aproveitamento dos subprodutos (levedura, torta de filtro, melaço, bagaço de cana para co-geração de energia elétrica), além de implementar novas formas de organização e administração da produção. Além disso, muitas usinas procuraram melhorar seu balanço energético para gerar maiores excedentes de eletricidade ${ }^{3}$ para o mercado de energia elétrica.

O ambiente competitivo trouxe também uma redefinição da estrutura de mercado da produção, que vem passando por um processo de concentração, através das fusões e aquisições de empresas, inclusive com a entrada de capital estrangeiro (francês, alemão) no setor. Este movimento levou ao crescimento de grupos econômicos no setor de açúcar e álcool.

2 Dentre as principais mudanças ocorridas, citam-se a desregulamentação do setor sucroalcooleiro, ou seja, a drástica redução da intervenção estatal (ver Moraes, 2000) e a proibição da queima da cana-deaçúcar no processo de colheita, induzindo à colheita mecanizada.

3 As usinas de açúcar e destilarias de álcool do Brasil são auto-suficientes em energia elétrica, co-gerada através do uso do bagaço da cana-de-açúcar. Com o aumento da eficiência energética no processo de fabricação de açúcar e de álcool, elas passaram a vender o excedente de energia elétrica co-gerada. 
Alterações no processo produtivo trouxeram impactos importantes no mercado de trabalho: terceirização de serviços agrícolas e industriais e a mecanização do corte e plantio da cana-de-açúcar. Por sua vez, a proibição da queima da cana-de-açúcar como método de despalha, com a conseqüiente adoção da mecanização da colheita da cana-de-açúcar também reduziram a demanda por mão-de-obra. Este fator, aliado ao custo da mão-de-obra (salários mais contribuições), contribuíram para a adoção da mecanização. Conforme Ricci et al. (1994), na decisão da adoção da mecanização da colheita na região de Ribeirão Preto (SP), além da viabilidade econômica (comparação dos custos de colheita manual e mecanizada), os empresários consideraram a redução da dependência na mão-de-obra rural contratada.

Neste trabalho, pretende-se analisar a evolução dos indicadores do mercado de trabalho dos setores de cana-de-açúcar, açúcar e álcool, além de abordar aspectos do ambiente institucional e organizacional do setor.

\section{OBJETIVOS}

Este artigo tem como objetivo analisar o ambiente institucional e organizacional do setor sucroalcooleiro do Brasil, especificamente no que se refere aos aspectos trabalhistas (legislação, negociações salariais), e apresentar indicadores para o período 1992-2005 sobre o mercado de trabalho: evolução do número de trabalhadores, escolaridade, idade, formalização e rendimento.

\section{METODOLOGIA}

Os dados secundários foram extraídos da Pesquisa Nacional por Amostra de Domicílios (PNAD) ${ }^{4}$ do Instituto Brasileiro de Geografia e Estatística - IBGE, (diversos anos) e dos Registros Administrativos do Ministério do Trabalho e Emprego da RAIS. ${ }^{5}$

Antes do ano de 2003 não é possível separar nos dados da PNAD as usinas de açúcar e destilarias de álcool porque os mesmos estão agregados em nível de indústria

4 A PNAD fornece um panorama da ocupação formal e informal do Brasil, sendo elaborada desde 1967 (de forma descontínua). Possui caráter amostral; seu desenho é estabelecido a partir do censo populacional de 1991 e de 2000, e permite a expansão dos resultados para todas as áreas do País.

5 A RAIS possui informações de caráter sociodemográfico e profissional, podendo ser agregada/desagregada ao longo dos eixos temporais (1986 a 2000) espaciais (nacional, regional, estadual, municipal), econômico, segundo a natureza jurídica dos estabelecimentos empregadores e portes dos estabelecimentos. 
de alimentos e de combustíveis. Portanto, optou-se por utilizar os dados da PNAD somente para a análise dos empregados do setor de cana-de-açúcar.

Para se analisar a evolução dos dados dos três setores (cana-de-açúcar, açúcar e álcool) utilizou-se como fonte de dados primários os Registros Administrativos do Ministério do Trabalho e Emprego da RAIS, cujo alcance é de 90\% deste setor organizado da economia e traz dados somente do emprego formal.

É importante observar que os dados da PNAD e da RAIS não são comparáveis, visto que as metodologias da coleta dos dados de ambas diferem completamente: a RAIS constitui-se de censo do mercado formal de trabalho, sendo o questionário respondido pelo empregador, enquanto na PNAD a entrevista ocorre no domicílio do trabalhador. Neste caso, a unidade de análise é o estabelecimento, e a resposta do entrevistado refere-se ao emprego na atividade principal do estabelecimento (ou seja, se na unidade agrícola existirem outras culturas, se a cana-de-açúcar for considerada pelo empregado a atividade principal, entende-se que é empregado do setor de canade-açúcar). Contudo, usualmente observam-se as mesmas tendências dos dados de ambas as bases.

Foram realizadas entrevistas com os representantes dos Sindicatos de trabalhadores e patronais do Estado de São Paulo ${ }^{6}$ de modo a compreender o mecanismo das negociações salariais, bem como identificar as principais entidades representativas do setor.

\section{FERRAMENTAL TEÓRICO: A NOVA ECONOMIA INSTITUCIONAL}

North (1991, p. 97) evidencia o papel das instituições no crescimento e desenvolvimento econômico. O autor define: "Instituições são restrições construidas pelo homem que estruturam a interação social, politica e econômica ...”; as instituiçóes incluem qualquer forma de constrangimento criada pelos agentes para moldar as interações humanas.

As instituições consistem, portanto, tanto de restrições informais (sanções, tabus, costumes, tradições e códigos de conduta), como de regras formais (constituição, leis e direitos de propriedade). Seu principal papel em uma sociedade consiste em reduzir as incertezas através do estabelecimento de regras (nem sempre eficientes) para estruturar as interações humanas.

6 Em pesquisa futura almeja-se a realização das entrevistas em outros Estados produtores. 
Segundo o autor, as instituições afetam o resultado do desenvolvimento econômico devido aos seus efeitos sobre os custos de troca e de produção. Juntamente com a tecnologia empregada, elas determinam os custos de transação e de produção.

Desta forma, surge uma relação entre os diferentes tipos de instituições e o desenvolvimento econômico, e, da mesma forma que algumas instituições promovem o desenvolvimento, existem outras que se constituem em obstáculos para o mesmo. Alterações no ambiente institucional (legislaçôes, direitos de propriedade, códigos de ética) causam uma necessidade de adaptação dos contratos estabelecidos entre os agentes, já que alteram o funcionamento e a eficiência do sistema.

North (1993) salienta que alterações nestas variáveis influenciam o processo de crescimento e desenvolvimento econômico. Essas modificações procedentes da evolução nas relações da sociedade, da pressão de grupos e de interesses econômicos trazem conseqüências históricas, uma vez que este ambiente institucional molda e estrutura a maneira como uma sociedade se desenvolve, causando impacto ao desempenho das economias dos países.

Hubbard (1997) aponta que a microeconomia, tendo idealizado um mercado ideal, num ambiente de perfeita informação e comunicação, negligenciou os custos reais de se fazer os negócios: os atrasos, as incertezas, as barganhas, obstruções e malícias existentes; estes custos e as obrigações e direitos que as pessoas assumem para reduzilos são objetos de estudo da Nova Economia das Instituições.

Para o autor, no "coração" da economia institucional está o fazer, monitorar e fazer valer (enforcing) os contratos; a facilidade ou dificuldade em fazê-los, e os tipos de contratos feitos são determinados pelo nível e natureza dos custos de transação, subjacente ao qual está a extensão da informação imperfeita envolvendo uma transação.

Além disso, Hubbard (1997) salienta que a Nova Economia das Instituições (NEI) é caracterizada por duas proposições: (i) a natureza dos contratos é determinada pelas incertezas e garantias resultantes das condições de mercado e das instituições prevalecentes (direitos de propriedade, convençôes, estrutura de autoridades); (ii) as instituições prevalecentes são alteradas pelas ações sociais respondendo às mudanças nas tendências dos preços relativos.

Os contratos, as leis e as convenções de uma sociedade podem tanto evoluir em termos de redução dos custos de transação, como ir em direção oposta. As instituições podem beneficiar um grupo mais que outros ou à custa de outros, e, como seu processo de mudança é difícil e lento, prendem a sociedade em determinado padrão histórico que pode ou não favorecer o desenvolvimento. Visto desta forma, o próprio 
desenvolvimento econômico é determinado pela extensão na qual as instituições do país favorecem o crescimento econômico sustentável (Hubbard, 1997).

Alston (1998) salienta que alguns conceitos, tais como custos de transação, direitos de propriedade e compromissos confiáveis, são utilizados para determinar as ligações entre instituições e desempenho econômico.

Conforme o autor, as normas e leis da sociedade determinam os direitos de propriedade que os indivíduos possuem, tais como o direito de vender um ativo, o direito de usar e receber renda dele, ou o direito de legá-lo. Os direitos de propriedade fazem-se valer de três maneiras: os próprios indivíduos exercem seus direitos (por exemplo, pondo chaves nas portas), através de sanções sociais (exclusão, ostracismo), ou pelo poder de coerção do Estado (tal como a ação da polícia).

Os direitos de propriedade, juntamente com as normas existentes e a tecnologia, determinam os custos de produção (os custos de produção neoclássicos, associados aos custos de combinar os insumos para obter os produtos) e os de transação, que são os custos "invisíveis" da produção, incluindo os esforços de monitorar os trabalhos, coordenar os fatores físicos da produção e monitorar o uso do capital físico e financeiro empregado no processo produtivo.

Quanto à influência das normas e dos direitos de propriedade nos custos de transação, Alston (1998) exemplifica que se em uma determinada cultura as pessoas realmente acreditam no trabalho sério (por tradição ou por incentivos passados), então os custos de monitoramento são menores. Da mesma forma, se a legislação de uma sociedade permite, por exemplo, que se demitam facilmente os trabalhadores negligentes, os referidos custos também serão menores.

Dado o conjunto de instituições de uma sociedade, os contratos entre os agentes serão feitos de tal forma a minimizar a soma dos custos de transação e de produção, os quais acabam influenciando o desempenho econômico.

Neste trabalho, entende-se que a existência, alterações e aplicação mais efetiva das legislações trabalhista e ambiental do Brasil - principalmente a que se refere à proibição da queima da cana-de-açúcar no Estado de São Paulo - têm influência relevante na evolução do mercado de trabalho deste setor. 


\section{REVISÃO DA LITERATURA}

\subsection{Mecanização da colheita: impactos sobre o emprego}

Tanto inovações tecnológicas quanto mudanças no ambiente institucional têm impactos importantes sobre o emprego. Ricci et al. (1994) destacam que na área agrícola, pode-se citar três níveis de inovações tecnológicas com impactos sobre o mercado de trabalho: (i) inovações mecânicas (afetam a intensidade e ritmo da jornada de trabalho); (ii) inovações físico-químicas: modificam as condições naturais do solo e elevam a produtividade do trabalho; (iii) inovações biológicas (interferem na velocidade de rotação do capital e do trabalho).

Os autores citam que são quatro os impactos principais na lavoura canavieira decorrentes das inovações mecânicas: redução do tempo das tarefas realizadas, redução da demanda por mão-de-obra, redução da mão-de-obra residente na propriedade e mudança qualitativa na demanda por trabalhadores, já que as novas atividades - tratoristas, motoristas, operadores de máquinas - requerem maior grau de especialização dos trabalhadores.

Em São Paulo, conforme informação dos sindicatos patronais, atualmente o carregamento, transporte e cultivo da cana-de-açúcar são $100 \%$ mecanizados, sendo a colheita aproximadamente $35 \%$ mecanizada. Portanto, a colheita, que em média representa $30 \%$ do custo de produção da cana-de-açúcar, ainda utiliza um grande contingente de homens e máquinas (guinchos, caminhões).

Além dos fatores tecnológicos, no Estado de São Paulo, a legislação que proíbe a queima da cana-de-açúcar como método de despalha trouxe grande impacto sobre o número de trabalhadores empregados no corte da cana-de-açúcar.

A queima da cana-de-açúcar ainda é uma prática comum no Brasil, já que a colheita da cana é, na maior parte das vezes, feita manualmente por empregados safristas, após o emprego do fogo para despalha, com posterior corte e transporte.

O emprego do fogo, na forma de queima controlada é, reconhecidamente, procedimento agrícola, pastoril e florestal, sendo utilizado inclusive como medida fitossanitária. Requer, contudo, cuidados especiais, técnica e controle.

Em São Paulo, a Lei Estadual No 10.547, de 02 de maio de 2000, estipula os procedimentos, proibições, regras de execução e medidas de precaução a serem tomadas quando do emprego do fogo em práticas agrícolas. Nos termos da lei, é necessário 
que antes do emprego do fogo o interessado requeira ao Poder Público a expedição de "Autorização de Queima Controlada", sendo a Secretaria do Meio Ambiente responsável para expedir a referida autorização.

A queima prévia da cana-de-açúcar aumenta a produtividade do trabalhador porque evita a retirada da palha da cana. Como o cortador de cana-de-açúcar ganha por produtividade, as próprias convenções coletivas de trabalho estipulam que o corte manual deve ser de cana queimada. Colher a cana-de-açúcar crua, manualmente, é antieconômico, induzindo à mecanização da colheita.

O corte e a colheita mecanizada podem ser realizados, com a tecnologia atualmente disponível em escala comercial, em terrenos com declividade de até 12\%. Outros fatores do terreno, como a existência de riachos e sulcos profundos, dificultam a mecanização. Contudo, a lei $\mathrm{N}^{\circ}$ 11.241, de 19 de setembro de 2002, determinou que tal prática deve ser totalmente banida no Estado de São Paulo até o ano de 2021, tendo estipulado um cronograma gradativo de extinção da queima da cana-de-açúcar, iniciado na safra 2002.

Em várias regiões de São Paulo a mecanização da colheita já vinha sendo realizada antes mesmo da implantação da lei (por questóes econômicas e trabalhistas), e na safra 2005/06 verificou-se, em São Paulo, um percentual de mecanização maior do que o estipulado em lei: no primeiro ano, a redução prevista para as áreas mecanizáveis era de $20 \%$, tendo sido verificada na prática $30 \%$ de redução da queima nas áreas mecanizáveis.

É interessante observar que a velocidade de adoção da colheita mecanizada varia bastante entre as principais regióes produtoras do Estado de São Paulo (Ribeirão Preto e Piracicaba); enquanto na região de Ribeirão Preto estima-se que a mecanização tenha atingido em torno de $60 \%$ da colheita, em Piracicaba esta proporção é bem menor, ao redor de $20 \%$. Este fato pode ser explicado por diversos fatores: (i) a região de Ribeirão Preto é plana, favorecendo a mecanização com as máquinas atualmente disponíveis, enquanto mais de $70 \%$ das terras de Piracicaba têm declividade superior a $30 \%$; (ii) a estrutura fundiária entre ambas também é diferente: enquanto na região de Ribeirão Preto existe a predominância de grandes produtores, com escala que justifica a compra de uma máquina colhedora, em Piracicaba a grande maioria é de pequenos produtores, que não são capitalizados para adquirir colhedeiras mecânicas, além de não terem escala de produção eficiente para a colheita mecânica; (iii) o movimento sindical dos trabalhadores na região de Ribeirão Preto tem maior grau de organização, 
com elevado poder de barganha, ${ }^{7}$ tendo incentivado a adoção da colheita mecânica bem antes da legislação entrar em vigor.

A tendência de mecanização da colheita, principalmente na região Centro-Sul, é irreversível e tende a se acelerar por diversos motivos. Além dos anteriormente citados, nos anos recentes as usinas estão investindo em co-geração de energia elétrica a partir da queima de bagaço de cana, para comercialização de energia neste mercado. Além do bagaço, a palha também pode ser utilizada como matéria-prima para a co-geração de energia elétrica, o que estimula as usinas a deixarem de queimá-la.

A produtividade do trabalho com a colheita da cana crua manual cai muito (em média seis toneladas por dia por empregado para 2,5 toneladas por dia por empregado), o que inviabiliza a adoção desta prática, ou seja, a cana crua só é rentável se colhida mecanicamente. Vieira (2003) comparou o custo por tonelada de cana do corte manual com queima e do mecanizado sem queima em duas usinas no Estado de São Paulo. O autor verificou que na primeira usina o custo do corte mecânico é 52,6\% menor que o manual, e na segunda usina o custo do corte mecânico é $11 \%$ menor que o manual.

Portanto, além dos fatores institucionais - a legislação proibindo a queima da canade-açúcar e a aplicação mais efetiva da legislação trabalhista - a mecanização tende a se acelerar também em função do aumento de competitividade das usinas, principalmente com o desenvolvimento de máquinas menores, mais baratas, e com tecnologia que permita a colheita em terrenos com maior declividade.

A questão que emerge é a seguinte: a mecanização reduz a demanda por trabalhador, principalmente aqueles de baixa qualificação (grande parte dos trabalhadores da lavoura canavieira tem poucos anos de estudo), expulsando-os da atividade. Este fato implica a necessidade de qualificação e treinamento desta mão-de-obra para estar apta a atividades que exijam maior qualificação.

Guilhoto et al. (2002) estudaram os impactos diretos e indiretos sobre o emprego. Para isso, utilizaram um modelo inter-regional de insumo-produto para a economia brasileira de 1997, ao nível das cinco macrorregióes, considerando especificamente o setor de cana-de-açúcar.

Os autores consideraram três cenários possíveis: (i) aumento no uso da mecanização da colheita sem aumento da produtividade; (ii) aumento no uso da mecanização da colheita com aumentos de produtividade iguais entre as regiões produtoras; (iii) au-

7 Conforme Ricci et al. (1994), na região de Ribeirão Preto a greve dos colhedores de cana em 1984, quando $100 \%$ da cana era colhida manualmente, paralisou as usinas de açúcar e mostrou a força dos trabalhadores e a dependência das empresas. Desde então, houve incentivo para a adoção gradual da colheita mecanizada. 
mento no uso da mecanização da colheita com aumentos de produtividade diferentes entre as regiões produtoras. Para todos os cenários utilizaram uma proporção de colheita mecanizada de $50 \%$ para a região Norte e de $80 \%$ para as demais regióes.

Os autores verificaram que a redução do número de empregados devido à mecanização da colheita é de aproximadamente 243 mil no cenário I, 273 mil no cenário II e de 316 mil no cenário III.

\subsection{O ambiente institucional}

Os princípios que regem o mercado de trabalho no Brasil são as leis impostas pelo Estado e as convençốes estipuladas entre os sindicatos de classe (patronais e de trabalhadores), que são normas jurídicas previstas no Direito do Trabalho, conforme exposto a seguir:

(i) Constituição Federal - a lei maior do País; (ii) Consolidação das Leis Trabalhistas (CLT); (iii) Lei do Trabalhador Rural (5889/73) e o Decreto 73624/74 que regulamenta a referida lei; (iv) Lei № 10.192, de 14 de fevereiro de 2001, que dispóe sobre a Política Salarial; (v) Normas Coletivas (Convenções e Acordos entre as partes).

A legislação trabalhista brasileira é bastante rígida, permitindo flexibilização, através de normas coletivas firmadas entre as partes, somente em dois aspectos - salário e jornada de trabalho - que devem ser negociados segundo o previsto no direito coletivo do trabalho, através das Normas Coletivas.

Existem dois tipos de Normas Coletivas: as Convenções Coletivas do Trabalho, que envolvem negociações entre o Sindicato Patronal e o Sindicato Profissional (de trabalhadores), e os Acordos Coletivos - quando as empresas negociam diretamente com os Sindicatos profissionais. Quando existirem divergências entre as negociações firmadas entre as normas, prevalecerá o acordo mais vantajoso para o trabalhador.

As Convenções Coletivas de Trabalho, firmadas entre os Sindicatos Patronal e Profissional, são realizadas no âmbito de cada Estado da Federação, pelos respectivos sindicatos. Relaciona-se a seguir a legislação pertinente ao mercado de trabalho rural e urbano, bem como o aparato legal para a aplicação dos acordos e convençóes de trabalho.

\section{Constituição Federal}

A Constituição Federal (CF) do Brasil proclama serem direitos sociais a educação, a saúde, o trabalho, o lazer, a segurança, a previdência social, a proteção à maternidade 
e à infância, e a assistência aos desamparados (CF, artigo 6으. É a lei maior do País, à qual as demais estão subordinadas. Os artigos que tratam especificamente de questôes ligadas ao mercado de trabalho são relacionados a seguir.

Em seu artigo 7ำ são definidos alguns direitos constitucionais dos trabalhadores urbanos e rurais, além de outros que visam a melhoria de sua condição social. A organização sindical é tratada no artigo $5^{\circ}$, XVII. No artigo $8^{\circ}$ e seus incisos estão dispostas as classificações dos direitos sindicais (liberdade de constituição; liberdade de inscrição; direito de auto-organização; direito de exercício de atividade sindical; direito democrático; direito de independência e autonomia; direito de relacionamento ou de filiação em organizações sindicais internacionais; direito de proteção especial dos dirigentes eleitos).

\section{Consolidação das Leis do Trabalho - CLT}

As leis trabalhistas brasileiras cresceram de forma desordenada; eram esparsas, de modo que cada profissão tinha uma norma específica, critério que, além de prejudicar muitas outras profissões que ficaram fora da proteção legal, pecava pelos inconvenientes naturais da fragmentação. Em 1943, os textos legais existentes foram reunidos em um só diploma. Na elaboração da nova legislação foi-se muito além de uma simples compilação porque, embora denominada Consolidação, a publicação acrescentou inovações, aproximando-se de um verdadeiro Código. Surgiu, portanto, promulgada pelo Decreto-lei № 5.452 , de $1^{\circ}$ de maio de 1943, a Consolidação das Leis Trabalhistas - CLT (Nascimento, 2001, p.71).

A legislação trabalhista - CLT - deve regular todas as relações surgidas da prestação do trabalho subordinado, sejam quais forem as condições sujeitas ao contrato de trabalho. Porém, em alguns casos o direito do trabalho não se aplica no todo ou em parte, como com os servidores públicos, o trabalhador doméstico, o trabalhador rural e os empregados de missões estrangeiras.(Süssekind et al., 1991)

\section{Trabalho rural}

Antes do Estatuto do Trabalhador Rural (1963) aplicava-se também aos trabalhadores rurais as disposiçôes da Consolidação da Lei Trabalhista (CLT) relativas ao salário mínimo (artigo 76 da CLT); às férias (artigo 129 da CLT, parágrafo único); ao aviso prévio e às normas gerais sobre o contrato de trabalho (artigo 505 da CLT). A aplicação do artigo 76 implicava reconhecer-lhes o limite de oito horas para a jornada de trabalho. Tinham, ainda, o direito ao repouso semanal remunerado e à remuneração dos domingos e feriados, conforme a Lei № 605, de 5 de janeiro de 1949 (Süssekind et al., 1991) 
No entanto, na prática essa legislação foi em muitos pontos inaplicável por falta de condições de fiscalização e de atuação judicial adequada onde não existiam as Juntas de Conciliação e Julgamento da Justiça do Trabalho.

O Estatuto do Trabalhador Rural acabou sendo revogado pela Lei № 5.889, de 8 de junho de 1973, cujo critério é o da extensão, pura e simples, ao trabalhador rural, da legislação trabalhista aplicável ao trabalhador urbano, com algumas restriçóes, o que não alterou substancialmente o seu elenco de direitos.

A Lei № 5.889/73 é aplicável a todo trabalhador rural e não apenas aos empregados rurais (artigo 17). O empregador é entendido como toda pessoa que exerce atividade agroeconômica, inclusive a exploração industrial em estabelecimento agrário; por sua vez, o empregado rural é o trabalhador que presta serviços em propriedade rural, e mediante subordinação (Nascimento, 2001).

O contrato de trabalho pode ter duração determinada e indeterminada. São admitidos contratos de safra (Lei $\mathrm{N}^{\circ} 5.889 / 73$, artigo 14), nos quais o trabalhador fica, durante o plantio ou a colheita, adstrito ao emprego, terminando a relação de empregado com o fim da safra.

Dentre os direitos específicos do trabalhador rural estão o adicional noturno (de 25\%), portanto maior que o do trabalhador urbano (de $20 \%$ ), os descontos pela ocupação da moradia na propriedade rural, até o limite de $20 \%$, a dedução pelo fornecimento de alimentação, a preço da região, de até $25 \%$, e o descanso na jornada de trabalho após seis horas de trabalho contínuo.

A cessão pelo empregador de moradia e de sua infra-estrutura básica, assim como de bens destinados à produção para a subsistência pessoal e familiar do trabalhador, não integra o salário, desde que haja previsão do contrato escrito de trabalho, com testemunhas e notificação obrigatória ao sindicato dos trabalhadores (Lei № 9.300/96). A lei retirou a natureza salarial dessas utilidades. Desse modo, não se somam nem integram a remuneração, para nenhum fim, encargos sociais, recolhimento de FGTS, cálculo de $13^{\circ}$ salário etc. (Nascimento, 1991).

Como o salário mínimo (Lei № 5.889, artigo 11) a partir da Constituição de 1988 é devido desde a idade mínima da admissão (16 anos) ao trabalhador urbano, para o trabalhador rural também é devido, pois deve seguir a isonomia constitucional $(\mathrm{CF}$, artigo $\left.7^{\circ}\right)$.

Além das leis propriamente ditas, as sentenças normativas dispóem sobre direitos dos trabalhadores rurais, alguns comuns aos urbanos, outros específicos para a atividade rural, como: a manutenção, pelo empregador, à disposição dos trabalhadores, de 
receituário agronômico dos defensivos agrícolas para a prevenção e esclarecimentos sobre estes; o transporte urgente, pelo empregador, do acidentado no trabalho para atendimento médico; o oferecimento de condições de segurança nos veículos que transportam os trabalhadores para o local dos serviços; a proibição do carregamento de ferramentas de trabalho soltas junto às pessoas conduzidas nos veículos para os centros de trabalho; o fornecimento de água potável no local das atividades; a manutenção de caixas de medicamentos para primeiros socorros próximas dos locais em que os trabalhadores estiverem executando os serviços; a instalação de abrigos rústicos para proteção contra chuvas; a justificação da falta de um dia por mês ou dois meiodias para o chefe de família ir à cidade fazer compras etc. (Nascimento, 2001)

\section{Convenções e acordos coletivos}

Segundo Nascimento (1991, p. 234), "Convenção Coletiva é a norma jurídica resultante das negociações entre trabalhadores e os empregadores, para a autocomposição dos seus conflitos coletivos”. Está disposta na Consolidação das Leis Trabalhistas - CLT, nos artigos №s 611 ao 625 .

Seu fundamento desenvolve-se mediante negociações coletivas e será formal, quando os seus trâmites estiverem previstos em leis ou em outras convenções coletivas, ou informal, quando não existir essa disciplina, hipótese em que as negociações serão feitas de acordo com os atos e fases que os interessados resolverem.

Objetiva solucionar uma disputa trabalhista e, com isso, constituir ou declarar regras que servirão durante um prazo como norma para as relações entre trabalhadores e empregadores, com adesão automática aos contratos individuais de trabalho e às relações coletivas entre as organizaçóes sindicais e empresas.

Seus sujeitos são o grupo de trabalhadores por meio das suas representações e o grupo de empregadores, também legitimamente representados. Quando os sujeitos interessados são, de um lado, o grupo de trabalhadores pelas suas legítimas representações e, de outro lado, em vez do grupo de empregadores, uma empresa diretamente, ou mais de uma empresa, relacionando-se a disputa somente nesse âmbito mais estrito, há um Acordo Coletivo e não uma convenção.

A Consolidação das Leis Trabalhistas (CLT, artigo 617, parágrafo $1^{\circ}$ ) permitia aos trabalhadores, diretamente, a iniciativa de negociar havendo inércia das organizações sindicais. No entanto, como o artigo $8^{\circ}$, capítulo VI, da Constituição Federal considera obrigatória a participação dos sindicatos na negociação coletiva, é possível concluir que os trabalhadores não poderão mais negociar diretamente. A presença do 
sindicato é obrigatória, a menos que se entenda que a inércia do sindicato autoriza a substituição (Nascimento, 1991).

As Convenções ou Acordos atingem qualquer trabalhador do município, independente de ser filiado ao Sindicato, ou seja, atinge toda a categoria de trabalhadores da região. Nos municípios onde não existem sindicatos (ou naqueles municípios que não são filiados aos sindicatos das cidades vizinhas), valem as regras estipuladas na CLT além do piso salarial nacional da categoria estipulado pelas normas coletivas.

\section{Politica Salarial}

A Lei № 10.192, de 14 de fevereiro de 2001, em seu artigo 13 dispõe que "no acordo ou convenção e no dissídio coletivos, é vedada a estipulação ou fixação de cláusula de reajuste ou correção salarial automática vinculada a indice de preços”. E em seu parágrafo $2^{\circ}$ dispõe que "qualquer concessão de aumento salarial a titulo de produtividade deverá estar amparada em indicadores objetivos". Percebe-se, portanto, que a legislação brasileira não permite que os salários sejam vinculados automaticamente aos preços.

\subsection{O ambiente organizacional}

A organização dos assalariados rurais para a conquista e afirmação dos seus direitos sociais teve início no País na década de 50, no contexto de modernização da agricultura brasileira. Ao longo da década de 90, as relações de trabalho passaram por importantes mudanças, fruto da mecanização das etapas produtivas agrícolas e da automação da atividade industrial.

O sindicalismo brasileiro é organizado em três níveis: municipal, estadual e nacional. No nível municipal a representação da categoria é feita nos sindicatos (um mesmo sindicato pode englobar vários municípios vizinhos). Os Sindicatos normalmente são filiados à entidade estadual, denominada Federação. Por sua vez, as várias Federações costumam ser filiadas nacionalmente à Confederação.

No Brasil, pelo fato de as empresas do setor produzirem tanto álcool como açúcar, as representações patronais e profissionais são feitas segundo o enquadramento previsto na legislação vigente (art.577 da CLT), ou seja, conforme a atividade principal do empreendimento (açúcar ou álcool). Além disso, as usinas e destilarias também produzem cana-de-açúcar, tendo trabalhadores agrícolas contratados. Neste caso, as representações patronais e profissionais são feitas por outras entidades representativas. 
O Quadro 1 mostra as entidades representativas no Estado de São Paulo dos trabalhadores (das usinas de açúcar e destilarias de álcool e dos empregados rurais) e representativas dos proprietários.

QUADRO 1 - ENTIDADES DE CLASSE REPRESENTATIVAS DAS EMPRESAS E TRABALHADORES - SAOO PAULO

\begin{tabular}{|c|c|c|}
\hline Categoria & & Entidade Estadual \\
\hline \multirow{3}{*}{ 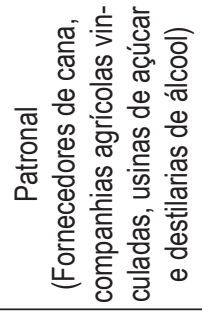 } & Rural(Cana-de-Açúcar) & $\begin{array}{l}\text { Federação da Agricultura do Estado de São Paulo (FAESP)* - base } \\
\text { inorganizada e Sindicatos Rurais Patronais }\end{array}$ \\
\hline & Álcool & $\begin{array}{l}\text { Sindicato da Indústria da Fabricação do Álcool no Estado de São } \\
\text { Paulo (SIFAESP) - base estadual }\end{array}$ \\
\hline & Açúcar & $\begin{array}{l}\text { Sindicato da Indústria do Açúcar no Estado de São Paulo (SIAESP) } \\
\text { - base estadual }\end{array}$ \\
\hline \multirow{3}{*}{ 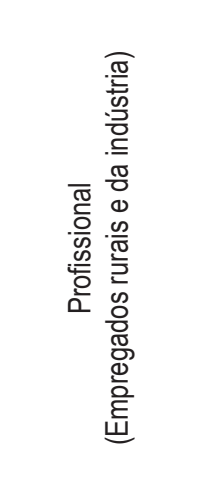 } & Rural(Cana-de-Açúcar) & $\begin{array}{l}\text { Federação dos Trabalhadores na Agricultura do Estado de São Paulo } \\
\text { (FETAESP) - até junho de } 2003 \\
\text { Federação dos Empregados Rurais do Estado de São Paulo (FE- } \\
\text { RAESP) - a partir de junho de } 2003 \text { e Sindicatos dos Empregados } \\
\text { Rurais }\end{array}$ \\
\hline & Álcool & $\begin{array}{l}\text { Federação dos Trabalhadores nas Indústrias Químicas e Farmacêu- } \\
\text { ticas do Estado de São Paulo (FEQUIMFAR) - base inorganizada e } \\
\text { Sindicatos Filiados }\end{array}$ \\
\hline & Açúcar & $\begin{array}{l}\text { Federação dos Trabalhadores nas Indústrias de Alimentação do } \\
\text { Estado de São Paulo (FETIASP) - base inorganizada e Sindicatos } \\
\text { Filiados }\end{array}$ \\
\hline
\end{tabular}

Fonte: Dados da pesquisa.

* As federações representam os municípios nos quais os Sindicatos não têm base ou extensão de base, ou seja, a sua base é a inorganizada.

Nota-se pelo Quadro 1 que no Estado de São Paulo, em nível estadual, existem três entidades representativas dos donos das usinas, destilarias e dos fornecedores de cana independentes, e três entidades representativas dos trabalhadores. 


\section{RESULTADOS}

\subsection{Evolução do número de empregados, nivel salarial, educação e idade dos empregados dos setores de cana-de-açúcar, açúcar e álcool}

Nesta seção apresentam-se os dados sobre a evolução do número de empregados do setor de açúcar e álcool do Brasil, incluindo os trabalhadores das usinas de açúcar, destilarias de álcool e da produção de cana-de-açúcar. Foram utilizadas duas fontes de dados: os da RAIS (que apresentam dados sobre o trabalho formal) e as PNAD (que trazem dados sobre o trabalho formal e informal).

\subsubsection{Mercado Formal (RAIS)}

Inicia-se a análise dos dados agregados para o Brasil, considerando-se suas regiões produtoras: Norte-Nordeste (NNE) e Centro-Sul (CS), ${ }^{8}$ cujas vocações, estratégias e níveis de produtividade são diferentes. O principal produto da região Norte-Nordeste é o açúcar, e do Centro-Sul era principalmente o álcool combustível, embora desde a safra 1991/92 sua produção de açúcar venha crescendo acentuadamente e nos dias de hoje as parcelas de cana-de-açúcar destinadas para álcool e para açúcar são aproximadamente iguais.

A Tabela 1 traz a evolução do número de trabalhadores formais envolvidos na produção de cana-de-açúcar, açúcar e álcool, para as duas regióes produtoras, e o total do Brasil, para os anos de 2000 a 2005. Nota-se que, para o Brasil como um todo, entre 2000 e 2005 , considerando-se os três setores (cana-de-açúcar, açúcar e álcool) conjuntamente, houve aumento expressivo de $52,9 \%$ do número de empregados formais, que passou de 642.848 empregados em 2000 para 982.604 em 2005. Em 2005, ao redor de 63\% dos empregados formais estavam na região Centro-Sul do País.

TABELA I - NÚMERO DE EMPREGADOS FORMAIS POR REGIÃO PRODUTORA - 2000 A 2005

\begin{tabular}{lccccc}
\hline Região Produtora & 2000 & 2001 & 2002 & 2004 & 2005 \\
\hline NNE & 250.224 & 302.720 & 289.507 & 343.026 & 364.443 \\
CS & 392.624 & 433.170 & 475.086 & 557.742 & 618.161 \\
Total Brasil & 642.848 & $\mathbf{7 3 5 . 8 9 0}$ & $\mathbf{7 6 4 . 5 9 3}$ & $\mathbf{9 0 0 . 7 6 8}$ & $\mathbf{9 8 2 . 6 0 4}$ \\
\hline
\end{tabular}

Fonte: Elaborado a partir de MT-b RAIS (vários anos).

8 Os Estados são agrupados conforme o período de safra. Os seguintes Estados fazem parte da região Norte-Nordeste: Alagoas, Bahia, Ceará, Maranhão, Pará, Paraíba, Pernambuco, Piauí, Rio Grande do Norte, Sergipe e Tocantins. Da região Centro-Sul: São Paulo, Paraná, Minas Gerais, Mato Grosso, Mato Grosso do Sul, Goiás, Rio de Janeiro, Espírito Santo, Rio Grande do Sul e Santa Catarina. 
A Tabela 2 traz o número de empregados formais por região produtora e por setor: cana-de-açúcar, açúcar e álcool. Percebe-se que o crescimento dos empregados formais das usinas de açúcar (101,9\%) e destilarias de álcool $(88,4 \%)$ do Brasil foi maior do que o dos trabalhadores rurais (16,2\%) envolvidos com a produção de cana-de-açúcar, provavelmente em decorrência do processo de mecanização da colheita de cana. É importante observar que neste período houve crescimento da produção de cana-deaçúcar: em 2000 a produção nacional foi de 325,33 milhões de toneladas, e em 2005 foi de 419,56 milhões (Ministério da Agricultura, Pecuária e Abastecimento, 2007), ou seja, um crescimento da produção da ordem de $28,9 \%$. Nota-se também que em 2000 ao redor de $55 \%$ do total eram empregados rurais, e em 2005 sua participação caiu para $42,2 \%$.

TABELA 2 - NÚMERO DE EMPREGADOS FORMAIS POR REGIÃO PRODUTORA E POR SETOR - 2000 A 2005

\begin{tabular}{llrrrrr}
\hline & Região & 2000 & 2001 & 2002 & 2004 & \multicolumn{1}{c}{2005} \\
\hline \multirow{3}{*}{ Cana-de-Açúcar } & NNE & 81.191 & 97.496 & 86.329 & 104.820 & 100.494 \\
& CS & 275.795 & 302.830 & 281.291 & 283.301 & 314.174 \\
& Total Brasil & 356.986 & 400.326 & 367.620 & 388.121 & 414.668 \\
\hline \multirow{3}{*}{ Açúcar } & NNE & 143.303 & 183.517 & 174.934 & 211.864 & 232.120 \\
& CS & 74.421 & 84.920 & 126.939 & 193.626 & 207.453 \\
& Total Brasil & $\mathbf{2 1 7 . 7 2 4}$ & $\mathbf{2 6 8 . 4 3 7}$ & $\mathbf{3 0 1 . 8 7 3}$ & $\mathbf{4 0 5 . 4 9 0}$ & $\mathbf{4 3 9 . 5 7 3}$ \\
\hline \multirow{2}{*}{ Álcool } & NNE & 25.730 & 21.707 & 28.244 & 26.342 & 31.829 \\
& CS & 42.408 & 45.420 & 66.856 & 80.815 & 96.534 \\
\hline \multirow{2}{*}{ Total Brasil três setores } & Total Brasil & $\mathbf{6 8 . 1 3 8}$ & $\mathbf{6 7 . 1 2 7}$ & $\mathbf{9 5 . 1 0 0}$ & $\mathbf{1 0 7 . 1 5 7}$ & $\mathbf{1 2 8 . 3 6 3}$ \\
\hline
\end{tabular}

Fonte: Elaborado a partir de MT-b RAIS (vários anos).

A Tabela 3 traz, para o ano de 2005, os dados referentes ao número de empregados formais para as regiões produtoras Norte-Nordeste e Centro-Sul, considerando as faixas etárias e graus de instrução, para os três setores.

Analisando-se os três setores agregados para o Brasil como um todo, verifica-se que o grupo de 30 a 39 anos é o maior (28,5\% do total). Agregando-se as categorias entre 18 e 49 anos têm-se $90,8 \%$ do total de empregados. É importante enfatizar a baixa participação $(0,2 \%)$ dos empregados com até 17 anos de idade. Os dados das regiões produtoras separadamente apresentam tendência similar à do Brasil: baixa proporção de empregados com menos de 17 anos e grande maioria dos empregados (ao redor de 90\%) com idade entre 18 e 49 anos.

Embora o número de anos de estudo dos trabalhadores dos setores analisados venha aumentando ao longo do tempo, observa-se que ainda é baixo. Considerando-se a 
educação dos três setores conjuntamente, a Tabela 3 indica que para o Brasil em 2005 prevaleceu o grupo com quatro anos de estudo incompletos $(35,2 \%)$, seguido pelo grupo de quatro anos completos $(18,8 \%)$. Nota-se quantidade importante $(11,3 \%)$ de analfabetos.

\section{TABELA 3 - NÚMERO DE TRABALHADORES DOS SETORES DE CANA-DE- AÇÚCAR, AÇÚCAR E ÁLCOOL PARA AS REGIÓES DO BRASIL, POR GRAU DE INSTRUÇÃO E FAIXA ETÁRIA - 2005}

\begin{tabular}{|c|c|c|c|c|c|c|c|}
\hline & Brasil & \multicolumn{3}{|c|}{ Norte-Nordeste } & \multicolumn{3}{|c|}{ Centro-Sul } \\
\hline Número de Empregados & 982.604 & \multicolumn{3}{|c|}{364.443} & \multicolumn{3}{|c|}{618.161} \\
\hline Grupos de idade & & Cana & Açúcar & Álcool & Cana & Açúcar & Álcoo \\
\hline Até 17 anos* & 1.514 & 221 & 229 & 14 & 668 & 302 & 80 \\
\hline 18 a 24 anos & 246.299 & 23.755 & 60.187 & 8.846 & 79.929 & 50.790 & 22.792 \\
\hline 25 a 29 anos & 191.272 & 18.687 & 47.093 & 6.606 & 61.209 & 39.272 & 18.405 \\
\hline 30 a 39 anos & 280.267 & 28.264 & 65.400 & 9.029 & 89.343 & 59.641 & 28.590 \\
\hline 40 a 49 anos & 174.458 & 18.409 & 39.229 & 5.215 & 54.624 & 39.126 & 17.855 \\
\hline 50 a 64 anos & 83.695 & 10.732 & 19.227 & 2.058 & 26.321 & 17.030 & 8.327 \\
\hline 65 anos ou mais & 5.097 & 424 & 755 & 61 & 2.080 & 1.292 & 485 \\
\hline Ignorado & 2 & 2 & 0 & 0 & 0 & 0 & 0 \\
\hline Total & 982.604 & 100.494 & 232.120 & 31.829 & 314.174 & 207.453 & 96.534 \\
\hline \multicolumn{8}{|l|}{ Educação } \\
\hline Analfabeto & 111.516 & 29.467 & 57.764 & 2.348 & 13.569 & 4.832 & 3.536 \\
\hline $4^{\mathrm{a}}$ série incompleta & 345.652 & 47.993 & 109.945 & 12.908 & 95.248 & 55.773 & 23.785 \\
\hline $4^{\mathrm{a}}$ série completa & 184.290 & 9.530 & 21.040 & 9.578 & 79.152 & 45.172 & 19.818 \\
\hline $8^{\mathrm{a}}$ série incompleta & 142.100 & 7.169 & 19.478 & 2.632 & 62.181 & 34.075 & 16.565 \\
\hline $8^{\mathrm{a}}$ série completa & 70.749 & 1.947 & 7.190 & 1.638 & 30.876 & 18.733 & 10.365 \\
\hline $2^{\circ}$ grau incompleto & 38.911 & 1.697 & 5.548 & 728 & 12.676 & 12.411 & 5.851 \\
\hline $2^{\circ}$ grau completo & 71.537 & 2.216 & 8.920 & 1.437 & 16.504 & 28.743 & 13.717 \\
\hline Superior incompleto & 5.518 & 143 & 572 & 123 & 1.465 & 2.195 & 1.020 \\
\hline Superior completo & 12.331 & 332 & 1.663 & 437 & 2.503 & 5.519 & 1.877 \\
\hline Total & 982.604 & 100.494 & 232.120 & 31.829 & 314.174 & 207.453 & 96.534 \\
\hline
\end{tabular}

Fonte: Ministério do Trabalho e Emprego - RAIS, 2005.

* A $1^{\text {a }}$ faixa etária disponível pelos registros da RAIS em 2005 é “até 17 anos”.

Quando se analisam as principais regiões produtoras separadamente, o perfil dos trabalhadores altera-se de forma importante. Nota-se que na região Norte-Nordeste, na cultura da cana-de-açúcar, $29,3 \%$ dos trabalhadores são analfabetos e 47,8\% têm quatro anos de estudo incompletos, perfazendo $77,1 \%$ dos trabalhadores; na produção de açúcar a baixa escolaridade também se verifica, com $24,9 \%$ analfabetos e $47,4 \%$ apresentando quatro anos de estudo incompletos (perfazendo $72,3 \%$ do total); na produção de álcool a situação é melhor, mas ainda prevalece o baixo nível de escolaridade: $7,4 \%$ de analfabetos e $40,6 \%$ com quatro anos de estudo incompletos.

A região Centro-Sul, por sua vez, apresenta indicadores de educação melhores: na cultura de cana-de-açúcar, 4,3\% são analfabetos e a proporção de trabalhadores com 
quatro anos de estudo incompletos é de 30,3\% (juntos respondendo por 34,6\% dos trabalhadores); verifica-se parcela de $25,2 \%$ de empregados com quatro anos completos de estudo. Na produção de açúcar, $2,3 \%$ são analfabetos e 17,8\% têm quatro anos de estudo incompletos, e na produção de álcool 3,7\% são analfabetos e $26,9 \%$ têm quatro anos de estudo incompletos.

\section{Remuneração Média Mensal}

TABELA 4 - REMUNER AÇÃO MÉDIA MENSAL* POR FAIXA ETÁRIA E POR NÍVEL DE ESCOLARIDADE, PARA OS SETORES DE CANA-DEAÇÚCAR, AÇÚCAR E ÁLCOOL E POR REGIÃO PRODUTORA 2005

\begin{tabular}{|c|c|c|c|c|c|c|c|}
\hline & \multirow[t]{2}{*}{ Brasil } & \multicolumn{3}{|c|}{ Norte-Nordeste } & \multicolumn{3}{|c|}{ Centro-Sul } \\
\hline & & $\begin{array}{c}\text { Cana } \\
\text { (R\$) }\end{array}$ & $\begin{array}{c}\text { Açúcar } \\
\text { (R\$) }\end{array}$ & $\begin{array}{c}\text { Álcool } \\
\text { (R\$) }\end{array}$ & $\begin{array}{c}\text { Cana } \\
\text { (R\$) }\end{array}$ & $\begin{array}{c}\text { Açúcar } \\
\text { (R\$) }\end{array}$ & $\begin{array}{c}\text { Álcool } \\
(\mathrm{R} \$)\end{array}$ \\
\hline \multicolumn{8}{|l|}{ Idade } \\
\hline Até 17 anos & 348,76 & 294,51 & 321,86 & 360,80 & 398,94 & 281,59 & 408,14 \\
\hline 18 a 24 anos & 551,64 & 393,09 & 407,87 & 416,39 & 633,02 & 667,36 & 605,82 \\
\hline 25 a 29 anos & 638,77 & 438,84 & 467,69 & 470,96 & 711,16 & 818,60 & 715,27 \\
\hline 30 a 39 anos & 705,58 & 472,21 & 523,99 & 521,06 & 737,66 & 948,73 & 802,44 \\
\hline 40 a 49 anos & 795,35 & 486,43 & 598,59 & 649,58 & 775,49 & 1121,63 & 934,53 \\
\hline 50 a 64 anos & 758,60 & 456,24 & 621,01 & 738,44 & 728,27 & 1103,79 & 860,89 \\
\hline 65 anos ou mais & 826,34 & 528,66 & 955,67 & 983,65 & 735,71 & 996,47 & 800,92 \\
\hline Desconhecido & 388,60 & 388,60 & 0,00 & 0,00 & 0,00 & 0,00 & 0,00 \\
\hline Total & 674,52 & 448,05 & 504,31 & 517,50 & 710,93 & 899,87 & 768,54 \\
\hline Escolaridade & & $\begin{array}{c}\text { Cana } \\
\text { (R\$) }\end{array}$ & $\begin{array}{c}\text { Açúcar } \\
\text { (R\$) }\end{array}$ & $\begin{array}{c}\text { Álcool } \\
(\mathrm{R} \$)\end{array}$ & $\begin{array}{c}\text { Cana } \\
\text { (R\$) }\end{array}$ & $\begin{array}{c}\text { Açúcar } \\
\text { (R\$) }\end{array}$ & $\begin{array}{c}\text { Álcool } \\
(\mathrm{R} \$)\end{array}$ \\
\hline Analfabeto & 417,92 & 382,07 & 382,05 & 394,26 & 571,72 & 578,45 & 508,79 \\
\hline $4^{\mathrm{a}}$ série incompleta & 527,09 & 422,83 & 437,58 & 441,26 & 603,31 & 655,49 & 591,46 \\
\hline $4^{\mathrm{a}}$ série completa & 720,20 & 467,62 & 528,99 & 504,95 & 748,51 & 881,91 & 667,04 \\
\hline $8^{a}$ série incompleta & 684,30 & 553,49 & 581,01 & 553,85 & 666,70 & 806,40 & 698,02 \\
\hline $8^{\text {a }}$ série completa & 780,71 & 552,39 & 682,94 & 550,04 & 746,38 & 905,82 & 804,01 \\
\hline $2^{\circ}$ grau incompleto & 756,70 & 580,15 & 628,63 & 562,03 & 750,49 & 837,04 & 796,61 \\
\hline $2^{\circ}$ grau completo & 981,27 & 882,21 & 921,64 & 741,37 & 948,98 & 1049,59 & 956,85 \\
\hline Superior incompleto & 1414,38 & 964,47 & 1696,33 & 1303,64 & 1159,88 & 1613,07 & 1270,66 \\
\hline Superior completo & 3353,09 & 2703,02 & 4116,29 & 2334,32 & 3001,69 & 3432,75 & 3263,44 \\
\hline Total & 674,52 & 448,05 & 504,31 & 517,50 & 710,93 & 899,87 & 768,54 \\
\hline
\end{tabular}

Fonte: Elaborado a partir dos dados da RAIS - Ministério do Trabalho e do Emprego, 2005.

* Valores correntes, em R\$ de 2005.

Os dados sobre a remuneração dos trabalhadores formais dos setores de cana-de-açúcar, açúcar e álcool estão na Tabela 4, que apresenta a remuneração em reais ( $\mathrm{R} \$$ ) por idade e por grau de instrução, para as regiões brasileiras, por produto específico. 
No que se refere à remuneração dos empregados, os dados da RAIS indicam que a média salarial mensal para os três setores no Brasil foi R \$ 674,52. Isoladamente, para o setor de açúcar a remuneração mensal média foi $\mathrm{R} \$ 690,99$, para o de álcool foi R \$ 706,29, e para os empregados da cana-de-açúcar foi R \$ 647,22. Considerando-se as regióes separadamente, pela Tabela 4 a média mensal para a indústria do açúcar na região NNE foi $\mathrm{R} \$ 504,31$ enquanto na região Centro-Sul foi R $\$ 899,87$ (78,4\% maior que da região NNE); na indústria do álcool, a média salarial da primeira região foi $\mathrm{R} \$ 517,50$ e na região Centro-Sul foi $\mathrm{R} \$ 768,54$ (48,5\% maior); a menor média salarial foi da cultura da cana-de-açúcar, que na região Norte-Nordeste foi $\mathrm{R} \$ 448,05$ e na região Centro-Sul foi $\mathrm{R} \$ 710,93$ (58,7\% maior). Como esperado, o nível de escolaridade está positivamente correlacionado com o rendimento.

Mercado de Trabalbo Formal: comparação dos indicadores de São Paulo, Paraná, Minas Gerais, Alagoas, e Pernambuco

Os três maiores Estados produtores de cana-de-açúcar da região Centro-Sul - São Paulo, Paraná, Minas Gerais - e os dois da região Norte-Nordeste - Alagoas e Pernambuco - foram responsáveis por aproximadamente $82,4 \%$ do total de 455.272 milhões de toneladas de cana-de-açúcar produzido no País em 2005 (Ministério da Agricultura, Pecuária e Abastecimento, 2007). A participação relativa destes Estados foi a seguinte: São Paulo (58,4\%); Paraná (7,7\%); Minas Gerais $(6,9 \%)$; Alagoas $(5,3 \%)$ e Pernambuco $(4,1 \%)$. Considerando-se a importância relativa destes Estados, faz-se uma análise comparativa dos seus indicadores salariais para o ano de 2005.

A Tabela 5 traz o número de empregados destes Estados para 2005. Nota-se que os envolvidos com a produção de cana-de-açúcar, de açúcar e de álcool para os referidos Estados - aproximadamente 794,6 mil empregados - representaram 80,9\% do total de empregados nestas atividades em todo o Brasil naquele ano.

O maior contingente de empregados está no Estado de São Paulo - 385.533 empregados - representando 39,2\% da agroindústria canavieira brasileira. A seguir, destacamse Pernambuco (15\%), Alagoas (14,1\%), Paraná (7\%) e Minas Gerais $(5,6 \%)$. 
TABELA 5 - COMPARAÇÃO ENTRE O NÚMERO DE EMPREGADOS E A REMUNER AÇÂO MÉDIA MENSAL* PARA OS PRINCIPAIS ESTADOS PRODUTORES - 2005

\begin{tabular}{|c|c|c|c|c|c|c|c|c|}
\hline & \multicolumn{2}{|c|}{ Cana-de-Açúcar } & \multicolumn{2}{|c|}{ Açúcar } & \multicolumn{2}{|c|}{ Álcool } & \multicolumn{2}{|c|}{ Total } \\
\hline & $\begin{array}{l}\text { Número de } \\
\text { empregados }\end{array}$ & $\begin{array}{c}\text { Remuneração } \\
\text { Média }\end{array}$ & $\begin{array}{l}\text { Número de } \\
\text { empregados }\end{array}$ & $\begin{array}{c}\text { Remuneração } \\
\text { Média }\end{array}$ & $\begin{array}{l}\text { Número de } \\
\text { empregados }\end{array}$ & $\begin{array}{c}\text { Remuneração } \\
\text { Média }\end{array}$ & $\begin{array}{l}\text { Número de } \\
\text { empregados }\end{array}$ & $\begin{array}{c}\text { Remuneração } \\
\text { Média }\end{array}$ \\
\hline $\mathrm{SP}$ & 220.517 & 753,79 & 131.867 & $1.031,70$ & 33.149 & 886,98 & 385.533 & 860,30 \\
\hline PE & 55.358 & 434,44 & 90.379 & 477,96 & 1.210 & 875,08 & 146.972 & 464,84 \\
\hline$A L$ & 8.702 & 380,86 & 119.345 & 514,28 & 10.744 & 477,74 & 138.791 & 503,09 \\
\hline PR & 21.146 & 527,18 & 27.122 & 563,27 & 20.274 & 567,80 & 68.542 & 553,47 \\
\hline MG & 16.897 & 650,12 & 28.626 & 708,95 & 9.280 & 663,58 & 54.803 & 683,13 \\
\hline $\mathrm{BR}$ & 414.668 & 647,22 & 439.573 & 690,99 & 128.363 & 706,29 & 982.604 & 674,52 \\
\hline
\end{tabular}

Fonte: Elaborada a partir de dados da RAIS.Ministério do Trabalho e Emprego, 2002.

* Valores correntes, em R\$ de 2005

Considerando-se as médias salariais mensais em 2005 dos empregados formais dos três setores (cana-de-açúcar, açúcar e álcool) conjuntamente, que no Estado de São Paulo foi R\$ 860,30, nota-se que neste Estado a média salarial é 27,5\% maior que a média nacional (R\$ 674,52). Analisando os setores separadamente, os trabalhadores da indústria do álcool em São Paulo receberam salários 25,6\% mais altos do que a média brasileira, os da indústria do açúcar $49,3 \%$ mais altos e os da lavoura canavieira foram $16,5 \%$ maiores.

Comparando-se as remunerações de São Paulo com os demais Estados, verifica-se que este Estado apresenta a melhor remuneração para os três setores. Tomando-se os salários médios mensais de São Paulo como base, nota-se que:

(i) os salários médios mensais dos empregados rurais são: 42,4\% menores em Pernambuco, 49,5\% menores em Alagoas, 30,1\% menores no Paraná e 13,8\% menores em Minas Gerais; (ii) os salários médios mensais dos trabalhadores das usinas de açúcar são: 53,7\% menores em Pernambuco, 50,2\% menores em Alagoas, 45,4\% menores no Paraná, 31,3\% menores em Minas Gerais; (iii) os salários médios mensais dos trabalhadores das destilarias de álcool são 1,3\% menores em Pernambuco, 46,1\% menores em Alagoas, 36\% menores no Paraná e 25,2\% menores em Minas Gerais.

Algumas hipóteses podem ser levantadas para explicar as diferenças salariais entre as regiões produtoras: a primeira refere-se ao nível educacional: espera-se que quanto maior o nível educacional maior a remuneração, o que explica os salários mais baixos dos Estados do Nordeste; a segunda hipótese refere-se à influência do ambiente 
institucional e organizacional: verificou-se na pesquisa a existência em São Paulo de sindicatos de trabalhadores organizados e atuantes, com forte influência nas negociações salariais (informações preliminares sobre os outros Estados indicaram baixa atuação ou mesmo inexistência de sindicatos em outros Estados); a terceira refere-se à maior produtividade dos empregados do Estado de São Paulo, justificando salários melhores neste Estado.

\subsubsection{Evolução do Mercado de Trabalho do setor de cana-de-açúcar (PNAD) ${ }^{9}$}

A Tabela 6 traz a evolução do número de empregados (permanentes e temporários) da produção de cana-de-açúcar, entre 1992 e 2005.

TABELA 6 - CANA-DE-AÇÚCAR: EVOLUÇÃO DO NÚMERO DE EMPREGADOS PERMANENTES E TEMPORÁRIOS

\begin{tabular}{lcc|cc|c}
\hline & \multicolumn{2}{c|}{ Permanente } & \multicolumn{2}{c}{ Temporário } & \\
\cline { 2 - 5 } Anos $^{*}$ & $\begin{array}{c}\text { Número de } \\
\text { empregados }\end{array}$ & Participação (\%) & $\begin{array}{c}\text { Número de empre- } \\
\text { gados }\end{array}$ & Participação (\%) & Total \\
\hline 1992 & 368.684 & 54,7 & 305.946 & 45,3 & 674.630 \\
1993 & 373.903 & 60,6 & 242.766 & 39,4 & 616.669 \\
1995 & 380.099 & 61,4 & 238.797 & 48,6 & 618.896 \\
1996 & 378.273 & 59,1 & 260.873 & 40,8 & 639.146 \\
1997 & 323.699 & 57,8 & 236.012 & 42,1 & 559.711 \\
1998 & 322.601 & 70,7 & 133.368 & 29,2 & 455.969 \\
1999 & 300.098 & 65 & 161.410 & 35 & 461.508 \\
2001 & 222.418 & 53,6 & 192.671 & 46,4 & 415.089 \\
2002 & 246.357 & 54,6 & 205.000 & 45,4 & 415.357 \\
2003 & 229.981 & 51,2 & 218.902 & 48,8 & 448.883 \\
2004 & 252.394 & 51,1 & 241.682 & 48,9 & 494.076 \\
2005 & 293.631 & 56,6 & 225.566 & 43,4 & 519.197 \\
\hline
\end{tabular}

Fonte: PNAD, vários anos.

* Não há pesquisa (PNAD) nos anos de 1994 e 2000.

Nota-se que a participação de empregados permanentes e temporários não apresentou uma tendência clara; contudo, a participação dos empregados permanentes sempre se mostrou mais alta durante o período analisado. Observa-se uma redução de $23 \%$

9 A fim de comparação com os anos anteriores, foram excluídos os dados da antiga região Norte Rural, visto que até 2003 esta região não era contemplada pela pesquisa. 
no número total de empregados no período analisado, a despeito do crescimento da ordem de $54,6 \%$ da produção de cana-de-açúcar, em parte devido ao aumento da mecanização da colheita da cana-de-açúcar, que vem sendo adotada tanto por razões econômicas quanto legais (no Estado de São Paulo).

A evolução dos empregados formais (com registro em carteira) e informais (sem registro em carteira), do setor de cana-de-açúcar para o Brasil, regiões produtoras e para o Estado da São Paulo é mostrada na Tabela 7. Observa-se que a participação dos empregados formais do setor de cana-de-açúcar no Brasil tem aumentado.

Considerando-se os dados agregados para o Brasil, nota-se que estes passaram de 53,6\% em 1992 para 72,9\% em 2005. Em 1992, a região Norte-Nordeste tinha $42,3 \%$ de empregados formais, e em 2005 aumentou para 60,8\%; na região CentroSul, a proporção foi de 66\% em 1992 para 85,8\% em 2005. O Estado de São Paulo, o maior produtor de cana-de-açúcar do Brasil, apresentou os melhores indicadores: a formalização passou de 80,4\% em 1992 para 93,8\% em 2005. Pode-se notar que, embora a formalidade esteja aumentando de forma geral, o número de empregados informais ainda é bastante elevado na região Norte-Nordeste.

TABELA 7 - CANA-DE-AÇÚCAR: EVOLUÇÃO DO NÚMERO DE EMPREGADOS FORMAIS E INFORMAIS NO BRASIL - 1992 A 2005 - ANOS SELECIONADOS

\begin{tabular}{lcc|rc|rr|rc}
\hline & \multicolumn{2}{c|}{1992} & \multicolumn{2}{c|}{2003} & \multicolumn{2}{c|}{2004} & \multicolumn{2}{c}{2005} \\
\cline { 2 - 8 } & Total & Formais & Total & Formais & Total & Formais & Total & Formais \\
\hline Brasil & 674.630 & $53,6 \%$ & 448.883 & $68,8 \%$ & 494.076 & $69,6 \%$ & 519.197 & $72,9 \%$ \\
NNE & 352.905 & $42,3 \%$ & 261.283 & $58,9 \%$ & 245.050 & $59 \%$ & 268.759 & $60,8 \%$ \\
CS & 321.725 & $66,0 \%$ & 187.600 & $82,8 \%$ & 249.026 & $79,9 \%$ & 250.438 & $85,8 \%$ \\
SP & 149.360 & $80,4 \%$ & 124.534 & $88,4 \%$ & 179.156 & $86,6 \%$ & 153.719 & $93,8 \%$ \\
\hline
\end{tabular}

Fonte: PNAD, vários anos.

Estes dados corroboram as informações prestadas pelos sindicatos patronais e de empregados do Estado de São Paulo durante a pesquisa de campo, que afirmaram que mais de $90 \%$ da mão-de-obra envolvida na produção de cana-de-açúcar, açúcar e álcool atualmente é formal.

Na Tabela 8 é mostrada a evolução da distribuição do número de empregados do setor da cana-de-açúcar, por grupo de idade e educação entre 1992 e 2005. Observa-se a queda da participação dos empregados com até 15 anos de idade: ${ }^{10}$ reduziu-se de $9 \%$

10 A Constituição Federal de 1988 , em seu artigo $7^{\circ}$, admite o trabalho a partir dos 16 anos, exceto nos casos de trabalho noturno, perigoso ou insalubre, para os quais a idade legal mínima é 18 anos. Pela referida CF (art. 222), admite-se o trabalho a partir dos 14 anos na condição de aprendiz. 
em 1992 (60.000 empregados) para 0,8\% em 2005 (totalizando 4.108 empregados), indicando redução importante da utilização da mão-de-obra infantil na produção de cana-de-açúcar do Brasil. Esta mesma tendência, embora em menor intensidade, é observada no grupo de idade de 15 a 20 anos: sua participação passou de 19,3\% em 1992 para 12,2\% em 2005. A idade média dos empregados deste setor em 2005, segundo os dados da PNAD, é 33,4 anos. A Tabela 9, por sua vez, apresenta a evolução do número de empregados por faixa de anos de estudo. Observa-se que, em 1992, $87,9 \%$ dos empregados tinham até quatro anos de estudo, sendo $46,2 \%$ analfabetos. Em 2005 a situação melhorou um pouco, mas ainda é preocupante: 70\% dos empregados da cana-de-açúcar do Brasil têm até quatro anos de estudo, e 29,4\%, ou seja, 154.598 empregados são analfabetos.

TABELA 8 - CANA-DE-AÇÚCAR: EVOLUÇÃO DO NÚMERO DE EMPREGADOS NO BRASIL POR FAIXA ETÁRIA

\begin{tabular}{|c|c|c|c|c|c|c|c|c|c|c|}
\hline \multirow{2}{*}{$\begin{array}{l}\text { Faixa } \\
\text { etária }\end{array}$} & \multicolumn{2}{|c|}{1992} & \multicolumn{2}{|c|}{1993} & \multicolumn{2}{|c|}{1995} & \multicolumn{2}{|c|}{1998} & \multicolumn{2}{|c|}{1999} \\
\hline & $\begin{array}{l}\text { N. de Em- } \\
\text { pregados }\end{array}$ & $\begin{array}{c}\% \\
\text { total }\end{array}$ & $\begin{array}{l}\text { N. de Em- } \\
\text { pregados }\end{array}$ & $\begin{array}{c}\% \\
\text { total }\end{array}$ & $\begin{array}{l}\text { N. de Em- } \\
\text { pregados }\end{array}$ & $\begin{array}{l}\% \\
\text { total }\end{array}$ & $\begin{array}{l}\text { N. de Em- } \\
\text { pregados }\end{array}$ & $\begin{array}{l}\% \\
\text { total }\end{array}$ & $\begin{array}{l}\text { N. de Em- } \\
\text { pregados }\end{array}$ & $\begin{array}{c}\% \\
\text { total }\end{array}$ \\
\hline $10-15$ & 60.418 & 9.0 & 36.439 & 5.9 & 38.793 & 6.3 & 10.965 & 2,4 & 3.304 & 0,7 \\
\hline $15-20$ & 130.501 & 19.3 & 117.464 & 19.1 & 134.221 & 21.7 & 77.642 & 17,0 & 56.948 & 12,3 \\
\hline $20-30$ & 196.547 & 29.1 & 178.790 & 29.0 & 172.872 & 27.9 & 135.170 & 29,6 & 151.173 & 32,8 \\
\hline $30-40$ & 122.696 & 18.2 & 119.919 & 19.5 & 119.099 & 19.2 & 109.080 & 23,9 & 116.927 & 25,3 \\
\hline $40-50$ & 82.659 & 12.3 & 95.978 & 15.6 & 83.274 & 13.5 & 69.068 & 15,2 & 69.564 & 15,1 \\
\hline $50-60$ & 56.138 & 8.3 & 49.107 & 8.0 & 52.775 & 8.5 & 37.513 & 8,2 & 49.298 & 10,7 \\
\hline$>60$ & 25.671 & 3.8 & 18.188 & 3.0 & 17.862 & 2.9 & 16.531 & 3,6 & 14.294 & 3,1 \\
\hline Total & 674.630 & 100 & 615.885 & 100 & 618.896 & 100 & 455.969 & 100 & 461.508 & 100 \\
\hline \multirow{2}{*}{$\begin{array}{l}\text { Faixa } \\
\text { etária }\end{array}$} & \multicolumn{2}{|c|}{2001} & \multicolumn{2}{|c|}{2002} & \multicolumn{2}{|c|}{2003} & \multicolumn{2}{|c|}{2004} & \multicolumn{2}{|c|}{2005} \\
\hline & $\begin{array}{l}\text { N. de Em- } \\
\text { pregados }\end{array}$ & $\begin{array}{c}\% \\
\text { total }\end{array}$ & $\begin{array}{l}\text { N. de Em- } \\
\text { pregados }\end{array}$ & $\begin{array}{c}\% \\
\text { total }\end{array}$ & $\begin{array}{l}\text { N. de Em- } \\
\text { pregados }\end{array}$ & $\%$ total & $\begin{array}{l}\text { N. de Em- } \\
\text { pregados }\end{array}$ & $\%$ total & $\begin{array}{l}\text { N. de Em- } \\
\text { pregados }\end{array}$ & $\begin{array}{l}\% \\
\text { total }\end{array}$ \\
\hline $10-15$ & 7.791 & 1,9 & 4.143 & 0,9 & 3.245 & 0,7 & 3.072 & 0,6 & 4.108 & 0,8 \\
\hline $15-20$ & 46.716 & 11,3 & 58.649 & 13,0 & 56.203 & 12,5 & 50.637 & 10,3 & 63.472 & 12,2 \\
\hline $20-30$ & 125.067 & 30,1 & 163.180 & 36,2 & 156.330 & 34,8 & 150.358 & 30,4 & 185.950 & 35,8 \\
\hline $30-40$ & 117.653 & 28,3 & 111.451 & 24,7 & 116.385 & 25,9 & 136.222 & 27,6 & 121.676 & 23,4 \\
\hline $40-50$ & 71.110 & 17,1 & 67.013 & 14,9 & 62.348 & 13,9 & 89.775 & 18,1 & 84.917 & 16,4 \\
\hline $50-60$ & 36.999 & 8,9 & 35.703 & 7,9 & 39.563 & 8,8 & 54.635 & 11,1 & 46.679 & 9,0 \\
\hline$>60$ & 9.753 & 2,4 & 11.218 & 2,5 & 14.809 & 3,3 & 9.377 & 1,9 & 12.395 & 2,4 \\
\hline Total & 415.089 & 100 & 451.357 & 100 & 448.883 & 100 & 494.076 & 100 & 519.197 & 100 \\
\hline
\end{tabular}

Fonte: Elaborado a partir de dados da PNAD (vários anos). 
TABELA 9 - CANA-DE-AÇÚCAR: EVOLUÇÃO DO NÚMERO DE EMPREGADOS NO BRASIL POR FAIXA DE ANOS DE ESTUDO

\begin{tabular}{|c|c|c|c|c|c|c|c|c|c|c|}
\hline \multirow{2}{*}{$\begin{array}{l}\text { Educação } \\
\text { Anos de } \\
\text { estudo }\end{array}$} & \multicolumn{2}{|l|}{1992} & \multicolumn{2}{|c|}{1993} & \multicolumn{2}{|l|}{1995} & \multicolumn{2}{|c|}{1998} & \multicolumn{2}{|c|}{1999} \\
\hline & $\begin{array}{l}\text { N. de em- } \\
\text { pregados }\end{array}$ & $\begin{array}{l}\% \\
\text { total }\end{array}$ & $\begin{array}{l}\text { N. de em- } \\
\text { pregados }\end{array}$ & $\begin{array}{l}\% \\
\text { total }\end{array}$ & $\begin{array}{l}\text { N. de em- } \\
\text { pregados }\end{array}$ & $\begin{array}{c}\% \\
\text { total }\end{array}$ & $\begin{array}{l}\text { N. de em- } \\
\text { pregados }\end{array}$ & $\begin{array}{l}\% \\
\text { total }\end{array}$ & $\begin{array}{l}\text { N. de em- } \\
\text { pregados }\end{array}$ & $\begin{array}{l}\% \\
\text { total }\end{array}$ \\
\hline 0 & 311.098 & 46,2 & 216.745 & 35,2 & 265.359 & 42,9 & 166.715 & 36,6 & 166.152 & 36,2 \\
\hline 1 a 3 & 197.142 & 29,3 & 208.650 & 33,8 & 166.340 & 26,9 & 136.585 & 30,0 & 136.249 & 29,7 \\
\hline 4 & 83.635 & 12,4 & 112.897 & 18,3 & 91.177 & 14,7 & 70.505 & 15,4 & 62.839 & 13,7 \\
\hline 5 a 7 & 61.717 & 9,2 & 56.190 & 9,1 & 71.754 & 11,6 & 51.977 & 11,4 & 58.405 & 12,7 \\
\hline 8 & 14.223 & 2,1 & 13.380 & 2,2 & 9.078 & 1,5 & 17.000 & 3,7 & 15.409 & 3,4 \\
\hline 9 a 10 & 1.952 & 0,3 & 3.922 & 0,6 & 4.823 & 0,8 & 5.969 & 1,3 & 10.753 & 2,3 \\
\hline 11 & 3.449 & 0,5 & 3.138 & 0,5 & 6.275 & 1,0 & 5.014 & 1,1 & 7.332 & 1,6 \\
\hline 14 ou mais & 0 & 0,0 & 1.747 & 0,3 & 4.090 & 0,6 & 2.204 & 0,5 & 2.045 & 0,5 \\
\hline Total & 673.216 & 100 & 616.669 & 100 & 618,896 & 100 & 455.969 & 100 & 459.184 & 100 \\
\hline Educação & \multicolumn{2}{|l|}{2001} & \multicolumn{2}{|c|}{2002} & \multicolumn{2}{|l|}{2003} & \multicolumn{2}{|c|}{2004} & \multicolumn{2}{|l|}{2005} \\
\hline $\begin{array}{l}\text { Anos de } \\
\text { estudo }\end{array}$ & $\begin{array}{l}\text { N. de em- } \\
\text { pregados }\end{array}$ & $\begin{array}{c}\% \\
\text { total }\end{array}$ & $\begin{array}{l}\text { N. de em- } \\
\text { pregados }\end{array}$ & $\begin{array}{c}\% \\
\text { total }\end{array}$ & $\begin{array}{l}\text { N. de em- } \\
\text { pregados }\end{array}$ & $\begin{array}{c}\% \\
\text { total }\end{array}$ & $\begin{array}{l}\text { N. de em- } \\
\text { pregados }\end{array}$ & $\begin{array}{c}\% \\
\text { total }\end{array}$ & $\begin{array}{l}\text { N. de em- } \\
\text { pregados }\end{array}$ & $\begin{array}{c}\% \\
\text { total }\end{array}$ \\
\hline 0 & 153.720 & 37,1 & 166.173 & 36,8 & 157.006 & 34,9 & 159.154 & 32,4 & 154.598 & 29,4 \\
\hline 1 a 3 & 117.484 & 28,4 & 124.374 & 27,6 & 119.437 & 26,5 & 112.218 & 22,3 & 121.656 & 23,6 \\
\hline 4 & 63.405 & 15,3 & 57.975 & 12,8 & 71.653 & 16 & 87.451 & 17,8 & 87.681 & 17,0 \\
\hline 5 a 7 & 48.955 & 11,8 & 60.716 & 13,4 & 63.627 & 14,1 & 74.279 & 15,1 & 73.270 & 14,2 \\
\hline 8 & 15.501 & 3,8 & 17.028 & 3,8 & 17.216 & 3,8 & 27.537 & 3,4 & 30.278 & 5,9 \\
\hline 9 a 10 & 7.025 & 1,7 & 5.366 & 1,2 & 8.970 & 2,0 & 12.732 & 2,6 & 16.534 & 3,2 \\
\hline 11 & 7.637 & 1,9 & 18.886 & 4,2 & 11.918 & 2,6 & 16.678 & 3,4 & 29.299 & 5,7 \\
\hline 14 ou mais & 0 & 0,0 & 839 & 0,2 & 483 & 0,1 & 857 & 0,2 & 5.881 & \\
\hline Total & 413.727 & 100 & 451.357 & 100 & 450.310 & 100 & 490.906 & 100 & 519.197 & 100 \\
\hline
\end{tabular}

Fonte: Elaborado a partir de dados da PNAD (vários anos).

\section{CONCLUSÕES}

O setor de açúcar e álcool do Brasil passou por profundas mudanças nos anos recentes, iniciadas com a desregulamentação estatal, em 1999, e acentuando-se com maior inserção no globalizado mercado internacional. Estas mudanças trouxeram vários impactos, incluindo a adoção de novas estratégias empresariais visando aumento de competitividade, e mudanças tecnológicas na área industrial e agrícola, com efeitos sobre o emprego. 
Além disso, alterações no ambiente institucional, como a proibição da queima da cana-de-açúcar como método de despalha no Estado de São Paulo e a aplicação mais efetiva da legislação trabalhista induziram à mecanização e reduziram o número de empregados envolvidos com a colheita manual da cana-de-açúcar, a despeito do crescimento da produção. Os impactos positivos referem-se ao aumento da formalização, ao crescimento dos níveis salariais e redução do uso de trabalho infantil, principalmente no Estado de São Paulo, o maior Estado produtor.

A existência de um sólido aparato institucional (legislação trabalhista, regulamentações, acordos e convenções coletivas de trabalho) e, especificamente no Estado de São Paulo, ${ }^{11}$ a existência de sindicatos patronais e de trabalhadores organizados e atuantes têm possibilitado que as negociações aconteçam de forma amigável e permitiram que diversos benefícios fossem incorporados aos rendimentos dos trabalhadores nos últimos anos (auxílio-saúde, educação etc). A atuação dos sindicatos no que se refere às negociações salariais pode ser um dos fatores que explicam as diferenças de salários entre os diversos Estados produtores, além dos níveis de escolaridade, dentre outras causas, a serem mais bem exploradas em pesquisas futuras.

Conforme os dados da RAIS, o número de empregados formais do setor no Brasil em 2005 foi de 982.604 trabalhadores, distribuídos entre a produção de cana-deaçúcar $(42,2 \%)$, produção de açúcar $(44,75 \%)$ e produção de álcool $(13,1 \%)$. Do total de trabalhadores, $37,1 \%$ pertenciam à região Norte-Nordeste e $62,9 \%$ à região Centro-Sul.

Considerando-se os principais Estados produtores, o maior grupo de trabalhadores formais (385.533) em 2005 situava-se em São Paulo, representando 39,2\% do total brasileiro. Para o ano de 2005, para o Brasil como um todo, os maiores salários médios mensais foram recebidos pelos trabalhadores da indústria do álcool (R $\$ 706,29)$, seguidos pelos da indústria do açúcar $(\mathrm{R} \$ 698,99)$ e pelos empregados agrícolas ( $\mathrm{R} \$$ $647,22)$.

No maior Estado produtor - São Paulo - as médias salariais em 2005 foram maiores do que a média brasileira: os trabalhadores da indústria do açúcar deste Estado receberam salários 49,3\% maiores do que a média brasileira; na indústria do álcool a diferença foi de $25,6 \%$ e para a cana-de-açúcar foi de $16,5 \%$.

Segundo os dados da PNAD (que contemplam os empregados formais e informais), verificou-se uma redução de $23 \%$ dos empregados do setor de cana-de-açúcar entre 1992 e 2005: em 1992 eram 670.099 empregados, e em 2005 eram 519.197. Essa

11 A pesquisa de campo contemplou somente o Estado de São Paulo, devendo ser ampliada para outros Estados em pesquisa futura. 
redução foi provavelmente impulsionada pela mecanização, já que no período houve um crescimento da produção de cana da ordem de $54,6 \%$.

Quanto à formalização, dos 450.130 empregados do setor de cana-de-açúcar em 2005, $72,9 \%$ eram formais (registrados), restando $27,1 \%$ na informalidade. Para o Estado de São Paulo, os indicadores são melhores: 144.188 empregados formais, que representam $93,8 \%$ do total.

A aplicação efetiva da legislação trabalhista teve o impacto positivo de reduzir o trabalho infantil e propiciar melhorias nas condições de trabalho. Além disso, a grande exposição do Brasil no comércio externo e as retaliações de seus principais competidores induzem as empresas exportadoras a ter maior preocupação com as questóes ambientais e trabalhistas.

Para pesquisas futuras, sugerem-se algumas questões relevantes que não foram abordadas neste trabalho. Primeiramente, a pesquisa de campo sobre a atuação dos sindicatos de classe contemplou somente o Estado de São Paulo, sendo importante ampliá-la para outros Estados; além disso, não se adotou indicador qualitativo sobre a qualidade de vida percebida pelos trabalhadores do setor; da mesma forma não foi objetivo da pesquisa analisar a oferta e demanda da mão-de-obra das regiões e setores analisados, bem como a dinâmica da política envolvendo a mão-de-obra da agroindústria canavieira.

\section{REFERÊNCIAS BIBLIOGRÁFICAS}

Alston, L. J. A framework for understanding the New Institutional Economics. In: SEMINÁRIO BRASILEIRO SOBRE A NOVA ECONOMIA INSTITUCIONAL, 1., São Paulo, 1998. Anais. São Paulo: Universidade de São Paulo, 1998

BRASIL. Constituição Federal de 1988. Lopes, M. A. R. (Coord.). $4^{\circ}$ ed. São Paulo: Editora Revista dos Tribunais, 1999.

. Lei n. 10.192, de 14 de fevereiro de 2001.

. Ministério do Trabalho e Emprego. Registros Administrativos. RAIS. Brasília, vários anos. CD- ROM.

Guilhoto, J.J.; Barros, A.L.M.; Marjotta-Maistro, M.C.; Istake, M. Mechanization process of the sugar cane harvest and its direct and indirect impact over the employment in Brazil and in its 5 macro regions. São Paulo: IPE-USP (Texto de Seminários N. $09 / 2002,09 / 05 / 2002$ ) 
Hubbard, M. The "New Institutional Economics" in agricultural development: insights and challenges. Journal of Agricultural Economics, v.48, n.2, p.239-249, 1997.

INSTITUTO BRASILEIRO DE GEOGRAFIA E ESTATÍSTICA - IBGE. Pesquisa nacional por Amostra de Domicílios - PNAD. Rio de Janeiro, vários anos. CDROM.

MINISTÉRIO DA AGRICULTURA, PECUÁRIA E ABASTECIMENTO. http:// www.agricultuta.gov.br. Acessado em 27/01/2007.

Moraes, A. Direito constitucional. $5^{\circ}$ ed. Revisada e ampliada. São Paulo: Atlas, 1999. $754 \mathrm{p}$.

Moraes, M. A. F. D. A desregulamentação do setor sucroalcooleiro do Brasil. Americana: Caminho Editorial, 2000. 238p.

Nascimento, A. M. Curso de direito do trabalho: história e teoria geral do direito do trabalho: relações individuais e coletivas do trabalho. $17^{\circ} \mathrm{ed}$. rev. e atual. São Paulo: Saraiva, 2001. 1004 p.

North, D. C. The New Institutional Economics and Development. St Louis: Washington University, 1993. 1991. . Institutions. Journal of Economics Perspectives, n. 5, p. 97-112, Winter,

Pinto, A.L.T.; Windt, M.C.V.S.; Siqueira, L.E.A. Consolidação das Leis do Trabalho. $28^{\circ}$ ed. São Paulo: Saraiva, 2001.

Ricci, R; Alves, F. J. C.; Novaes, J. R. P. Mercado de Trabalho do Setor Sucroalcooleiro no Brasil. Brasília: IPEA, 1994. 176p. (Estudos de Política Agrícola,15. Documentos de Trabalho)

Süssekind, A.; Maranhão, D.; Vianna, S. Instituições de direito do trabalho. v. 1. $12^{\circ}$ ed. São Paulo: LTr, 1991. 651 p.

Vian, C. E. F. Agroinduistria canavieira. Estratégias competitivas e modernização. Campinas, SP: Editora Átomo, 2003. 216p.

Vieira, G. Avaliação do custo, produtividade e geração de emprego no corte de cana-deaçúcar, manual e mecanizado, com e sem queima prévia. Dissertação (Mestrado). Universidade Estadual Paulista "Júlio Mesquita Filho". UNESP. Faculdade de Ciências Agronômicas. Botucatu, 2003. 114p. 